\title{
Aerobic Bacteria in Crèche Environment and their Antibiotic Sensitivity
}

\author{
Aemere Ogunlaja* and Esther Foloshade Kehinde
}

Biological Sciences Department, Redeemer's University, Redemption city, Mowe, Ogun state, Nigeria

*Corresponding author

\section{Keywords}

Children,

Antibiotics,

Crèches, Bacteria, pathogens

Article Info

Accepted:

18 April 2019

Available Online:

10 May 2019

\section{A B S T R A C T}

The numbers of crèche facilities are on the increase because more women are becoming financial supports to their families in developing countries. Children become exposed to pathogenic agents most of which are resistant to antibiotic as re-infection is commonly placed in such facilities. In African countries, there are hardly minimum standards or monitoring of such facilities. This study focused on isolating aerobic pathogenic bacteria and determining their antibiotic sensitivity using four crèches in Redemption city. With sterile swabs, samples were collected from floors, toys and care-givers hands and analysed by standard microbiological methods. Antibiotic sensitivity data was subjected to student t-test. The isolates included Staphylococcus aureus, Staphylococcus spp, Bacillus megaterium, Bacillus subtilis, Lactobacillus fermenti, Bacillus spp, Neisseria spp, Aeromonas spp, Aeromonas sobria, Proteus mirabilis, Proteus vulgaris, Klebsiella oxytoca, Enterobacter intermedius, Streptococcus spp, Corynebacterium spp, Pseudomonas spp and Enterobacter spp. S. aureus had the highest incidence (27.2\%) while A. sobria, P. mirabilis, $K$. oxytoa, and E. intermedius equally had the lowest incidence $(0.5 \%)$. The floor had the highest isolates followed by hands of care givers and toys. Ampicillin was not significantly effective on the bacteria isolates $(\mathrm{P}=0.094)$. No isolate showed significant resistance to antibiotics. The pathogenic bacteria isolates indicated the potential risk the children are exposed to, however, most of the bacteria isolates could effectively be treated with common antibiotics.

\section{Introduction}

A crèche is a place where infants and children are kept for a particular period of time for nursing care, nutrition, sleep, excretion, general comfort and follow up of the children (Wallace and Ebrahim,
1981). In many countries, specifically the industrialized ones, the need is determined mostly by the population of mothers working outside their homes who have infants and children of pre-school age. However, the population of working mothers with pre-school children is not 
always used for assessing the need for daycare centres (WHO, 1964).

Children cared for at crèches are said to show two to three times greater risk of acquiring infections, which impacts both on individual health and on the spreading of diseases through the community (Nesti and Goldbaum, 2007) and crèches are areas with special epidemiological characteristics, since the children populations are at risk for the transmission of infectious diseases (Gensheimer, 1994). The risk is independent of factors such as age, race, social class and others that may be of relevance to the incidence rates of the diseases in question (Osterholm, 1994). Infants have habits that enables the spread of diseases, such as putting their hands and objects in their mouths, very close interpersonal contact, faecal incontinence during the phase prior to the acquirement of sphincter muscle control, the lack of habit of hand washing and other hygienic practices and the need for constant direct physical contact with adults (Thompson, 1994). Groups of children therefore become the focus of the multiplication of cases of infectious diseases and their spreading to the surrounding community (Overturf, 1994).

Once an agent has been introduced into a daycare environment its further transmission depends partly on the characteristics of the microorganism itself. An infectious agent transmission within a child care centre is also influenced by the characteristics of the children attending, their age, sex, immunological status, presence of siblings at home, educational level of the parent, socioeconomic level of the family and length of time enrolled at the centre. This is most influenced by characteristics of the centre itself, such as the total number of children, class sizes, number of workers per child, and precisely the hygiene involved in handling children and the care taken in the environment (Huskins, 2000). Children that go to daycare centers have an increased risk of acquiring respiratory infections, acute otitis media, diarrheal diseases, invasive bacterial diseases such as Streptococcus pneumonia, Haemoplilus influenza etc, hepatitis A and infections by CMV and Varicella-zoster (Churchill and Pickering, 1997). There is evidence of an increased risk of disease transmission among children at daycare when compared with those not attending schools, although there is no evidence that children with recurring infections at preschool ages become more resistant to infection with age (Ball et al., 2002a). In a fair amount of occurrence in preschool age children cared for out-ofhome, infectious disease can be attributed to the daycare centre (Ball et al., 2002b).

Children are not the only people involved in the spread of diseases at daycare centers, family members and workers are also at increased risk of acquiring the same diseases as the children (Fogarty, 1996). Nevertheless, daycare centers offer the opportunity of assuring healthy children, through stimulation of development, safer environments, better nutritional support, better vaccination coverage and health promotion (Zoritch et al., 1998). The fact that transmission of infectious diseases is aided by the increased exposure at daycare centers, child day care and infectious diseases gains further importance in the light of the development of new infectious conditions in the community. This can be caused by virulent agents resistant to common antibiotics used for such infections in children for example methicillin resistant Staphylococcus aureus. These infections are mainly cutaneous abscesses, but can manifest in the form of severe conditions such as pneumonia endocarditis and toxic shock syndrome (Nesti and Goldbaum, 2007). 
The use of antibiotics for treatment of infections or diseases caused by pathogenic organisms has been on the increase in developing countries where prevention of diseases by virtue of improved hygiene and provision of sanitation is impractical. The prevalence of antibiotics resistance in bacterial isolates worldwide may be due to the selection and spread of resistant organisms in developing countries which can often be traced to complex socioeconomic and behavioural experience (Hart and Kariuki, 1998).

The recommendation of WHO for ensuring proper drug use can be adapted to combat the growth of community acquired antibiotics by health care professionals, unskilled consultants and patients can be relieved by examining antibiotics, limiting antibiotic choice, developing prescription guidelines, and emphasizing continuing medical and public education.

There are insufficient information on the recommended hygiene standards, no routine check-up and no stipulated regulatory bodies in some countries, yet there are growing numbers of emerging crèches in such countries. This investigation focused on isolating aerobic pathogenic bacteria present in four crèches on Redemption camp, Mowe, Ogun State, Nigeria. It also involved comparing the prevalence of the isolated bacterial amongst the four crèches and determining the sensitivity of antibiotics on the isolated bacterial.

\section{Materials and Methods}

\section{Sample site description / Collection of samples}

The Redemption is a growing community with four crèches which were used for this study. They are, King is coming (KIC) crèche, Redeemer's university (RUN) crèche, Christ Redeemer's Nursery and primary school (CRNPS) crèche and God's Heritage crèche and they are designated CR1, CR2, CR3 and CR4. Samples were taken from different areas, object and persons in the crèche and its environment using sterile cotton tipped swab moistened with brain heart infusion broth (BHI). Samples were taken from the floor, toys and teacher's hand and they were designated FL, TY, and TH. These samples were taken after clean-up of each crèche. The age group of children in each crèche was 3 months to 2years. The number of classes in each crèche varied from 1 to 6 and the number of teacher's (care givers) in each crèche varied from 1 to 2 per class. The number of babies in total in each crèche varied from 20 to 40, a maximum of 10 babies per class. In each crèche, cleaning of the crèche and its environment is done for at least twice in a day i.e. morning before resumption to school and also after meal or after closing hours in the evening.

Samples were taken aseptically from the floor, toys and teacher's hands using sterile swabs. The culture media used in this study included Brain-heart infusion broth, MacConkey Agar, Blood Agar, Mannitol salt Agar, Nutrient Agar and Nutrient Broth. The sample swabs were aseptically streaked unto the mannitol salt Agar plates, MacConkey Agar plates and Blood Agar plates and incubated at $37^{\circ} \mathrm{C}$ for 24hours. The plates were observed for growth, distinct colonies and also distinctive cultural characteristics and subcultured to obtain a pure culture.

Microscopic characterization was done by Gram staining followed by biochemical tests including Catalase , Coagulase, Oxidase, Citrate Utilization, Motility, Indole, Urease, Motility test, Indole, Urease, Methyl red- Vogues Proskauer 
Test, Sugar fermentation and acid production (Atlas et al., 1995). Final identification of isolates was done by software (ABIS onlinewww.abis.online.com)

\section{Antibiotic susceptibility testing}

Sensitivity of isolates to antimicrobial agents was determined on Nutrient Agar plates using the disc diffusion method of Scott (1989). Interpretation of results was done measuring the zone sizes. Any zone diameter above or equal to $12 \mathrm{~mm}$ shows susceptibility to the antibiotics while that below $12 \mathrm{~mm}$ shows resistance to the antibiotics. All isolates were tested for sensitivity to the following antibiotics: Septrin $(30 \mu \mathrm{g})$, Chloranphenicol $(30 \mu \mathrm{g})$,

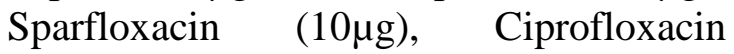
$(10 \mu \mathrm{g})$, Amoxacillin $(30 \mu \mathrm{g})$, Augmentin $(30 \mu \mathrm{g})$, Gentamycin $(10 \mu \mathrm{g})$, Pefloxacin $(30 \mu \mathrm{g}), \quad$ Tarivid $(10 \mu \mathrm{g}), \quad$ Streptomycin $(30 \mu \mathrm{g})$, Ampliclox $(30 \mu \mathrm{g})$, Zinnacef $(20 \mu \mathrm{g})$, Rocephin (25) and Erythromycin $(10 \mu \mathrm{g})$.

\section{Statistical analysis}

Data collected from susceptibility test were subjected to student t-test analyses and significant level was at $\mathrm{p} \leq 0.05$ using SPSS version 16.

\section{Results and Discussion}

Pathogenic organisms were isolated from the four crèches although they differ from one crèche to the other. A total of 18 bacterial isolates were identified, the bacterial isolates included; Staphylococcus aureus, Staphylococcus sp., Bacillus megaterium, Bacillus subtilis, Lactobacillus fermenti, Bacillus sp., Neisseria sp., Aeromonas sp., Aeromonas sobria, Aeromonas salmonicida, Proteus mirabilis, Proteus vulgaris, Klebsiella oxytoca, Enterobacter intermedius, Streptococcus sp., Corynebacterium sp., Pseudomonas sp. and Enterobacter sp. . Most of them were isolates commonly found in all the crèches including the floor, toys and teachers hands, with floor having the highest isolate (Table 1). CR4 was most contaminated. There were eight different bacterial isolates each from CR1 and CR2, seven isolates from CR3 and fourteen isolates from CR4 (Table 2). $S$. aureus was predominant having $27.2 \%$ occurrence while $P$. mirabilis, $K$. oxytoca, E. Intermedius and A. Sobria equally had the lowest occurrence having $0.5 \%$ (Table 2). Most of these organisms were enteric pathogenic bacteria, which found their way possibly through chance contamination from lack of good personal and public hygiene.

Antibiotic sensitivity data was subjected to student t-test. All antibiotics were significantly effective on the bacterial isolate except Amoxicillin $\quad(p=0.09$; $\mathrm{p} \geq 0.05$ ) which had no significant effect on the bacteria isolates (Table 3). No isolate showed significant resistance to antibiotics (Table 4).

Over recent decades, the population of children in crèches has increased drastically because; a number of parents need to go to work. Although, the objectives of these crèches, is to provide children with a secure environment for growth, development and erudition, it is not rare for communicable diseases to occur in these crèches because children have reasonably low status of immunity and the obstacles in upholding a high level of hygiene (Ashton et al., 2005; Nesti and Goldbaum, 2007). 
Table.1 Bacteria Isolated from different areas of the crèches

\begin{tabular}{|c|c|c|c|c|}
\hline SAMPLE & CR1 & CR2 & CR3 & CR4 \\
\hline FL & $\begin{array}{l}\text { Neisseria. sp. } \\
\text { Staphylococcus sp. } \\
\text { S. aureus } \\
\text { Aeromonas sp. } \\
\text { Coryn. sp. } \\
\text { Streptococcus sp. }\end{array}$ & $\begin{array}{l}\text { Neisseria sp. } \\
\text { S. aureus } \\
\text { Staph. sp. } \\
\text { Coryn. sp. } \\
\text { A. sobria }\end{array}$ & $\begin{array}{l}\text { Bacillus } s p . \\
\text { S. aureus } \\
\text { Coryn. sp. } \\
\text { P. vulgaris }\end{array}$ & $\begin{array}{l}\text { B. subtilis } \\
\text { Aeromonas sp. } \\
\text { Neisseria sp. } \\
\text { P. mirabilis } \\
\text { S. aureus } \\
\text { P. vulgaris } \\
\text { Staphylococcus sp. } \\
\text { Corynebacterium sp. } \\
\text { K. oxytoca } \\
\text { Streptococcus sp. }\end{array}$ \\
\hline TY & $\begin{array}{l}\text { Neisseria } s p . \\
\text { Staphylococcus sp. } \\
\text { S. aureus } \\
\text { L. fermenti } \\
\text { Streptococcus sp. }\end{array}$ & $\begin{array}{l}\text { Neisseria sp. } \\
\text { S.aureus } \\
\text { Staph. sp. } \\
\text { Aeromonas sp. } \\
\text { Streptococcus sp. } \\
\text { Bacillus sp. }\end{array}$ & $\begin{array}{l}\text { Bacillus sp. } \\
\text { S. aureus } \\
\text { Coryn. sp. } \\
\text { P. vulgaris } \\
\text { A. salmonicida }\end{array}$ & $\begin{array}{l}\text { Aeromonas sp. } \\
\text { Neisseria sp. } \\
\text { S. aureus } \\
\text { Staphylococcus sp, } \\
\text { Corynebacterium sp. } \\
\text { Streptococcus sp. } \\
\text { E. intermedius } \\
\text { Bacillus sp. }\end{array}$ \\
\hline TH & $\begin{array}{l}\text { Neisseria sp. } \\
\text { Staphylococcus } s p . \\
\text { S. aureus } \\
\text { Aeromonas } s p . \\
\text { Coryn. } s p . \\
\text { Streptococcus } s p . \\
\text { Enterobacter } s p .\end{array}$ & $\begin{array}{l}\text { Neisseria sp. } \\
\text { S. aureus } \\
\text { Staphy. sp. } \\
\text { Coryn. sp. } \\
\text { Aeromonas sp. }\end{array}$ & $\begin{array}{l}\text { S. aureus } \\
\text { Coryn. sp. } \\
\text { Neisseria sp. } \\
\text { A. salmonicida } \\
\text { B. megaterium }\end{array}$ & $\begin{array}{l}\text { Aeromonas sp. } \\
\text { Neisseria sp. } \\
\text { S. aureus } \\
\text { Corynebacterium sp. } \\
\text { Streptococcus sp. } \\
\text { Aeromonas sp. } \\
\text { B. megaterium } \\
\text { Pseudomonas sp. }\end{array}$ \\
\hline
\end{tabular}

KEYS: FL- Floor, TY- Toy, TH- Teacher's Hand, CR1- Crèche 1, CR2- Crèche 2, CR3Crèche 3, CR4- Crèche 4. 
Table.2 Occurrence of Bacterial isolate in each Crèche

\begin{tabular}{|c|c|c|c|c|c|c|c|c|c|c|}
\hline ISOLATE & \multicolumn{2}{|c|}{ CR1 } & \multicolumn{2}{|c|}{ CR2 } & \multicolumn{2}{|c|}{ CR3 } & \multicolumn{2}{|c|}{ CR4 } & \multicolumn{2}{|c|}{ Total Creches } \\
\hline & $\begin{array}{c}\text { Occurre } \\
\text { nce }\end{array}$ & $\begin{array}{c}\% \\
\text { Occur } \\
\text { rence }\end{array}$ & $\begin{array}{l}\text { Occur } \\
\text { rence }\end{array}$ & $\begin{array}{c}\% \\
\text { Occurren } \\
\text { ce }\end{array}$ & $\begin{array}{l}\text { Occur } \\
\text { rence }\end{array}$ & $\begin{array}{c}\% \\
\text { Occurre } \\
\text { nce }\end{array}$ & $\begin{array}{c}\text { Occurre } \\
\text { nce }\end{array}$ & $\begin{array}{c}\% \\
\text { Occurre } \\
\text { nce }\end{array}$ & $\begin{array}{c}\text { Total \% } \\
\text { Occurre } \\
\text { nce }\end{array}$ & $\begin{array}{c}\text { Total } \\
\text { Occurre } \\
\text { nce }(\%)\end{array}$ \\
\hline Lac. fermenti & 1 & 2.2 & 0 & 0 & 0 & 0 & 0 & 0 & 2.2 & 0.6 \\
\hline Bac. subtilis & 0 & 0 & 0 & 0 & 2 & 8 & 1 & 2 & 10 & 2.5 \\
\hline Bac. megaterium & 0 & 0 & 0 & 0 & 1 & 4 & 1 & 2 & 6 & 1.5 \\
\hline Coryn. sp. & 5 & 10.1 & 2 & 3.8 & 7 & 28 & 3 & 6 & 47.9 & 12 \\
\hline Staph. aureus & 12 & 26.1 & 12 & 22.6 & 9 & 36 & 12 & 24 & 108.7 & 27.2 \\
\hline Staphyloccus sp. & 11 & 24.4 & 6 & 11.3 & 0 & 0 & 7 & 14 & 49.7 & 12.4 \\
\hline Neiss. sp. & 11 & 24.4 & 26 & 49.1 & 2 & 8 & 7 & 14 & 95.5 & 23.9 \\
\hline Proteus vulgaris & 0 & 0 & 0 & 0 & 2 & 8 & 2 & 4 & 12 & 3 \\
\hline P. mirabilis & 0 & 0 & 0 & 0 & 0 & 0 & 1 & 2 & 2 & 0.5 \\
\hline Aeromonas sp. & 2 & 4.4 & 4 & 7.6 & 0 & 0 & 6 & 12 & 24 & 6 \\
\hline A.salmonicida & 0 & 0 & 0 & 0 & 2 & 8 & 0 & 0 & 8 & 2 \\
\hline A. sobria & 0 & 0 & 1 & 1.9 & 0 & 0 & 0 & 0 & 1.9 & 0.5 \\
\hline Enterobacter sp. & 1 & 2.2 & 0 & 0 & 0 & 0 & 0 & 0 & 2.2 & 0.6 \\
\hline E. intermedius & 0 & 0 & 0 & 0 & 0 & 0 & 1 & 2 & 2 & 0.5 \\
\hline Pseudomonas sp. & 2 & 4.4 & 0 & 0 & 0 & 0 & 1 & 2 & 6.6 & 1.6 \\
\hline K. oxytoca & 0 & 0 & 0 & 0 & 0 & 0 & 1 & 2 & 2 & 0.5 \\
\hline Bacillus sp. & 6 & 13.3 & 1 & 1.9 & 0 & 0 & 4 & 8 & 23.2 & 5.8 \\
\hline Streptococcus sp. & 3 & 6.7 & 1 & 1.9 & 0 & 0 & 3 & 6 & 14.6 & 3.7 \\
\hline Total & 54 & & & & & & & & & \\
\hline
\end{tabular}

KEYS: CR1- Crèche 1, CR2- Crèche 2, CR3- Crèche 3, CR4- Crèche 4. 
Table.3 Antimicrobial susceptibility patterns to antibiotics

\begin{tabular}{|l|c|c|}
\hline Antibiotics & $\begin{array}{c}\text { Mean zone of inhibition } \\
\text { of the antibiotics }\end{array}$ & $\mathbf{P} \leq \mathbf{0 . 0 5}$ \\
\hline SXT & $0.49 \pm 0.3$ & 0.005 \\
\hline CH & $0.60 \pm 0.3$ & 0.001 \\
\hline SP & $0.80 \pm 0.3$ & 0.000 \\
\hline CPX & $0.96 \pm 0.2$ & 0.000 \\
\hline AU & $0.27 \pm 0.1$ & 0.001 \\
\hline GN & $0.80 \pm 0.2$ & 0.000 \\
\hline PEF & $0.91 \pm 0.2$ & 0.000 \\
\hline OFX & $0.96 \pm 0.2$ & 0.000 \\
\hline S & $0.67 \pm 0.2$ & 0.000 \\
\hline APX & $0.28 \pm 0.2$ & 0.000 \\
\hline AM & $0.10 \pm 0.2$ & 0.094 \\
\hline R & $0.56 \pm 0.2$ & 0.000 \\
\hline E & $0.69 \pm 0.3$ & 0.000 \\
\hline $\mathbf{Z}$ & $0.53 \pm 0.3$ & 0.001 \\
\hline
\end{tabular}

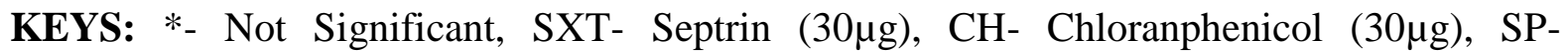
Sparfloxacin $(10 \mu \mathrm{g})$, CPX-Ciprofloxacin $(10 \mu \mathrm{g})$, AM- Amoxacillin $(30 \mu \mathrm{g})$, AU- Augmentin

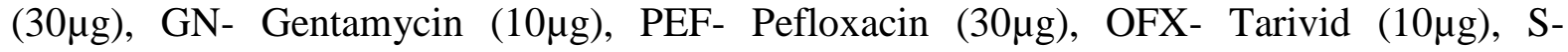
Streptomycin $(30 \mu \mathrm{g})$, APX- Ampliclox $(30 \mu \mathrm{g})$, Z- Zinnacef $(20 \mu \mathrm{g})$, R- Rocephin $(25 \mu \mathrm{g})$, EErythromycin $(10 \mu \mathrm{g})$.

Table.4 Antibiotic sensitivity of bacterial isolate

\begin{tabular}{|c|c|c|}
\hline Isolates & $\begin{array}{l}\text { Mean zone of inhibition } \\
\text { of all the antibiotics }\end{array}$ & $P \leq 0.05$ \\
\hline Neisseria sp. & $0.71 \pm 0.3$ & 0.000 \\
\hline P. mirabilis & $0.84 \pm 0.4$ & 0.000 \\
\hline P. vulgaris & $0.69 \pm 0.3$ & 0.000 \\
\hline E. intermedius & $0.75 \pm 0.2$ & 0.000 \\
\hline Aeromonas sp. & $0.49 \pm 0.4$ & 0.003 \\
\hline Pseudomonas sp. & $0.66 \pm 0.2$ & 0.000 \\
\hline Bacillus sp. & $0.73 \pm 0.3$ & 0.000 \\
\hline Staphylococcus sp. & $0.34 \pm 0.3$ & 0.011 \\
\hline B. megaterium & $0.63 \pm 0.4$ & 0.000 \\
\hline B. subtilis & $0.66 \pm 0.4$ & 0.000 \\
\hline K. oxytoca & $0.86 \pm 0.2$ & 0.000 \\
\hline Strep. sp. & $0.61 \pm 0.2$ & 0.000 \\
\hline S. aureus & $0.71 \pm 0.2$ & 0.000 \\
\hline Corynebacterium sp. & $0.59 \pm 0.3$ & 0.000 \\
\hline
\end{tabular}


The present work examined the different aerobic pathogenic bacteria from crèches in Redemption Camp (CR1, CR2, CR3 and CR4).

In this study, the types and number of microorganism isolated in the crèches differed from one another and were all pathogenic or opportunistic pathogens except Lactobacillus fermenti which can be used as a probiotic but in a study carried out by Olaitan and Adeleke, (2007), he discovered that the microorganisms he isolated were both pathogenic and non-pathogenic. The isolated bacteria includes; Staphylococcus aureus, Staphylococcus sp., Bacillus megaterium, Bacillus subtilis, Lactobacillus fermenti, Bacillus sp., Neisseria sp., Aeromonas sp., Aeromonas sobria, Aeromonas salmonicida, Proteus mirabilis, Proteus vulgaris, Klebsiella oxytoca, Enterobacter intermedius, Streptococcus sp., Corynebacterium sp., Pseudomonas sp. and Enterobacter sp. Most of the bacteria isolated were similar to the isolates in the study by Olaitan and Adeleke, (2007) in daycare centres.

Staphylococcus aureus had the highest rate of occurrence in all the crèches. This is because they are normally associated with the skin, skin glands and mucous membranes (Willey et al., 2010). This finding is in line with Olaitan and Adeleke, (2007) who isolated Staphylococcus aureus from all the crèches but was in contrast to the study carried out by Lesley et al. (2007) who isolated Bacillus sp. as the most common bacteria. The floors had the highest number of bacteria isolates as the floor is the major portion which receives dirts from footwares worn by persons. This poses a risk to especially crawling children (Ashton $e t$ al., 2005). Staphylococci infections occurs when the organism enters the body through breaks, cuts, and abrasions in the skin or mucous membranes (Pelczar, 1999).
Bacillus sp., Bacillus megaterium were isolated from CR2, CR3 and CR4 from the floor, toy and teacher's hands. This may be due to the ability of these bacteria to produce endospores which disperse rapidly in the atmosphere and are ubiquitous in soil and other environments (Lesley et al., 2007).

Corynebacterium sp. was isolated from all the crèches (CR1, CR2, CR3 and CR4) from the floor, toy and teacher's hands. This may be due to the fact that they are widely distributed in nature. They occur commonly in nature in the soil, water, plants and food products. It can also be found in the mucosa and normal skin flora of humans. Some are harmless saprophytes while some species can cause human diseases, which can be pathogenic to humans. It can be pathogenic to immunosuppressed patients (Willey et al., 2010).

Streptococcus sp. was isolated from CR1, CR2 and CR4 from the floor, toy and teacher's hands. This may be as a result of Streptococcus sp. being a normal flora of animals and humans. This is most probably as a result of poor hygiene and especially inadequate washing of hands after using the toilets or after attending to a child (Olaitan and Adeleke, 2007). Their numbers are restricted by non specific defence mechanisms that is, some species can cause diseases, either when the mechanisms fail, or when it has acquired extra virulent factors which make them pathogenic (CFSPH, 2005). Some species cause lobar pneumoniae and otitis media (inflammation of the middle ear) in young children (Willey et al., 2010). Aeromonas sp., Aeromonas salmonicida and Aeromonas sobria were isolated from CR1, CR2, CR3 and CR4. This may be as result of Aeromonas sp., being ubiquitous and a suspected cause of gastroenteritis because they occur in water, soil and food, specifically milk, fish and meat. These organisms can be 
transmitted by direct contact, person to person or subtly by fomites which are inanimate objects such as toys or consumption of contaminated food and water (Nesti and Goldbaum, 2007; WHO, 2006).

Proteus vulgaris was isolated from CR3 and CR4 from the toys and floor while Proteus mirabilis was isolated from CR4 from the floor. This may be as a result of Proteus sp. being ubiquitous, may be found in the soil, water and faecal matter. These organisms can be shed from the body, clothing, beddings, and nostrils and passed in the dust particles to other surfaces such as toys, floors etc (Itah and Ben, 2004). It is grouped with the Enterobacteriaceae and is it considered as a pathogenic organism for young individuals (PHAC, 2011).

Pseudomonas sp. was isolated from CR4 from teacher's hands. This may be as a result of the characteristics of the environment. The steady spilling of foods and liquids such as; milk in which these organisms can grow perfectly and most probably due to changing of diapers by the care takers. Also, they have the ability to produce biofilms which make them environmentally stable (Lesley et al., 2007; Willey et al., 2010).

Neisseria sp. was isolated from CR1, CR2, CR3 and CR4 from the hand, toy and teacher's hands. This may be as a result of some Neisseria sp., which are normal inhabitants of the upper respiratory tract and are part of the commensal flora of mucosal membrane of humans and can be transmitted by contact with droplets through coughing, sneezing and discharge from the nose and throat of infected persons, however, transmission can be rare due to low virulence. It can also be pathogenic to individuals who are immunosuppressed or immunocompromised (PHAC, 2011).
Lactobacillus fermenti is a rarely pathogenic bacterium which can be used as a probiotic strains in order to benefit health and it can be isolated from human colonic mucosal biopsy samples that posses antimicrobial activities against enteroinvasive and food borne pathogen (Marika and Mihkel, 2009). Although it is rarely pathogenic, it was isolated from CR1 from toy.

Among the antibiotics, only Amoxacillin showed no significant effect on the gram positive bacteria and No bacterial isolate showed significant resistance to the antibiotics. Antibiotic resistance has become one of the major health threats to humans due to increasing virulence and the survival of mutating pathogens (Yah and Eghafona 2007). It has been confirmed that the major selecting force in bacterial antibiotic resistance is the abuse or misuse of antibiotics (Okeke et al., 1999).

The need for more crèches is anticipated in the present world of gender equality resulting to increasing number of women in the workforce, however, children attending day care centres are at a higher risk of gastroenteritis diseases caused by a large number of enteric pathogens. The risk is increased due to high person to person transmission within a group in the care centres. This study revealed the presence of enteric pathogenic organisms $t$ in the crèches studied and these were probably spread by the hands of the children and employees. Monitoring bodies for crèches are recommended to be established in all countries to enact policies of minimum hygiene standards and routine quality assessment be ensured.

\section{References}

Ashton, Leigh and Wigan. 2005. Infection Control and Communicable Diseases 
guidelines for early years and child care. Available at: http://www.wigan.gov.uk/NR/rdonlyres/5 7143996-4DEF-4OE2-98FF9EDEF40948AO/O/InfectionControlAug 08.pdf. Accessed on 30 ${ }^{\text {th }}$ June, 2013.

Atlas, M.; Parks, C. and Brown, A. 1995. Laboratory Manual of Experimental Microbiology. Mosby - Year-Book, Inc., USA.

Ball, T.M., Holberg, C.J., Aldous, M.B., Martinez, F.D. and Wright, A.L. 2002a. Influence of attendance at day care on the common cold from birth through 13 years of age. Archive of Paediatrics and Adolescent Medicine, 156: 121-126.

Ball, T.M., Holberg, C.J., Aldous, M.B., Martinez, F.D. and Wright A.L. 2002b. Is there a common cold constitution? Ambulatory Paediatrics, 2:261-267.

Center for Food Security and Public health, 2005. Streptococcosis. Available at: http://www.cfsph.iastate.edu/Factsheets/p dfs/Streptococcosis.pdf. Accessed $30^{\text {th }}$ June, 2013.

Churchill, R.B. and Pickering, L.K. 1997. Infection control challenges in child care. Infectious Disease Clinics North America Journal, 11:347-365.

Fogarty, J. 1996. Infectious disease risk in crèche, day-care and pre-school. Irish Medical Journal, 89: 210, 212.

Gensheimer, K.F. 1994. A public health perspective on child care. Pediatrics, 946: 1116-1118.

Hart, C.A. and Kariuki, S. 1998. Antimicrobial resistance in developing countries. British Medical Journal, 317: 647-650.

Huskins, W.C. 2000. Transmission and control of infections in out-of home child care. Paediatric Infectious Disease Journal, 1910: 106-110.

Itah, A.Y. and Ben, A.E. 2004. Incidence of Enteric Bacteria and Staphylococcus aureus in Day Care Centers in Akwa
Ibom State, Nigeria. Southeast Asian Journal of tropical medicine and public health, 351: 202-209.

Lesley, L., Sara, T. and Scott, T.K. 2007. Culture Independent analysis of bacterial diversity in a childcare facility. Biomed Central Microbiology, 7:27.

Marika, M. and Mihkel, Z. 2009. Lactobacillus fermentum. An antimicrobial and antioxidative probiotic. Microbial Ecology in Health and Disease, 21: 1-27.

Nesti, M.M. and Goldbaum, M. 2007. Infectious diseases and daycare and preschool education. Journal of Paediatrics, 834: 299-312.

Okeke, I.N., Lamikanra, A. and Edelman, R. 1999. Socio-economic and behavioural factors leading to acquired bacterial resistance to antibiotics in developing countries. Emerging Infectious Disease, 5: 13-27

Olaitan, J. and Adeleke, O. 2007. Bacteria in Day Care Environment. The internet Journal of Microbiology, 3: 10.

Overturf, G.D. 1994. Endemic giardiasis in the United States-role of the day-care center. Clinical Infectious Diseases, 18:764-765.

Osterholm, M.T. 1994. Infectious disease in child care: an overview. Paediatrics, 946: 987-990.

Pelczar, M.J. 1999. Microbiology. 5th edition, MCGrew- Hill Incorporated. University of Washington U.S.A Pp 300.

Public Health Agency of Canada PHAC, 2011. Proteus spp: Pathogen Safety Data Sheet- Infectious Substances. Available at: http://www.phac-aspc.gc.ca/labbio/res/psds-ftss/proteus-eng.php. Accessed on 30 ${ }^{\text {th }}$ June, 2013.

Scott, A. 1989. Laboratory control of antimicrobial therapy. In: Practical medical microbiology Mackie and McCartney. ELBS, London Pp 161-181.

Thompson, S.C. 1994. Infectious diarrhoea in 
children: controlling transmission in the child care setting. Journal of Paediatrics in Child Health, 30: 210-219.

Wallace, H.M. and Ebrahim, G.J. 1981. Maternal and child Health around the world. The Macmillan Press Limited, London, Pp 241-243.

Willey, J.M., Sherwood, L.M., and Woolverton, C.J. 2011. Prescott's Microbiology. $8^{\text {th }}$ Edition. McGraw-Hill, New York, Pages 1070.

World Health Organization WHO, 1964. Care of children in day centres. Available at: http://whqlibdoc.who.int/php/WHO_PHP 24_part1.pdf. Accessed on $22^{\text {nd }}$ May, 2013.

World Health Organization WHO, 2006.
Guideline for drinking-water quality:

Microbial fact sheet. Available at: http://www.who.int/water_sanitation_heal th/dwq/gdwq3_11.pdf. Accessed $30^{\text {th }}$ June 2013.

Yah, C.S. and Eghafona, N.O. 2007. Plasmids: A Vehicle for Rapid Transfer of Antibiotic Resistance Markers of Salmonella species in Animals. Journal of Animal Science, 34: 86-92.

Zoritch, B., Roberts, I. and Oakley, A. 1998. The health and welfare effects of daycare: a systematic review of randomised controlled trials. Social Science Medicine, 47: 317-327.

\section{How to cite this article:}

Aemere Ogunlaja and Esther Foloshade Kehinde. 2019. Aerobic Bacteria in Crèche Environment and their Antibiotic Sensitivity. Int.J.Curr.Microbiol.App.Sci. 8(05): 2437-2447. doi: https://doi.org/10.20546/ijcmas.2019.805.288 